\title{
THE COST OF OWNING EMPLOYER STOCKS: LESSONS FROM TAIWAN
}

\author{
Yi-Tsung Lee, Yu-Jane Liu, and Ning Zhu*
}

CRR WP 2007-24

Released: December 2007

Draft Submitted: October 2007
Center for Retirement Research at Boston College Hovey House
140 Commonwealth Avenue
Chestnut Hill, MA 02467

Tel: 617-552-1762 Fax: 617-552-0191

http://www.bc.edu/crr

* Yi-Tsung Lee is a Professor in the Department of Accounting at the National Chengchi University. Yu-Jane Liu is a Professor in the Department of Finance at the National Chengchi University. Ning Zhu is an Assistant Professor of Finance at the University of California, Davis. The research reported herein was performed pursuant to a grant from the U.S. Social Security Administration (SSA) funded as part of the Retirement Research Consortium. The opinions and conclusions expressed are solely those of the authors and should not be construed as representing the opinions or policy of SSA, any agency of the Federal Government, the National Chengchi University, the University of California, Davis, or Boston College.

(C) 2007, by Yi-Tsung Lee, Yu-Jane Liu, and Ning Zhu. All rights reserved. Short sections of text, not to exceed two paragraphs, may be quoted without explicit permission provided that full credit, including $\odot$ notice, is given to the source. 


\title{
About the Center for Retirement Research
}

The Center for Retirement Research at Boston College, part of a consortium that includes parallel centers at the University of Michigan and the National Bureau of Economic Research, was established in 1998 through a grant from the Social Security Administration. The Center's mission is to produce first-class research and forge a strong link between the academic community and decision makers in the public and private sectors around an issue of critical importance to the nation's future. To achieve this mission, the Center sponsors a wide variety of research projects, transmits new findings to a broad audience, trains new scholars, and broadens access to valuable data sources.

\author{
Center for Retirement Research at Boston College \\ Hovey House \\ 140 Commonwealth Avenue \\ Chestnut Hill, MA 02467 \\ phone: 617-552-1762 fax: 617-552-0191 \\ e-mail: crr@bc.edu \\ www.bc.edu/crr
}

\author{
Affiliated Institutions: \\ American Enterprise Institute \\ The Brookings Institution \\ Center for Strategic and International Studies \\ Massachusetts Institute of Technology \\ Syracuse University \\ Urban Institute
}




\begin{abstract}
Using data on all employees at listed companies in Taiwan, we find that the bias toward employer stocks is generic to individual investor decision-making, but not limited to retirement plans. 71 percent of sample employees invest in employer stocks and the employer stocks make up on average 47 percent of employee equity portfolios. The under-diversification resulting from the bias toward employer stocks is highly costly. Holding current portfolio risk constant, employees forego 4.89 percent per annum in raw returns by investing in employer stocks, which represents 39.74 percent of their average 1998 salary income. Our findings have important implications for social security reform and retirement account management.
\end{abstract}




\section{Introduction}

During the past decade, many countries started using investment-based personal retirement accounts (i.e. 401(k) plans in the U.S.) to supplement or replace the pay-asyou-go pension system (Feldstein (1998), Leone and Anrig (1999)). To obtain higher returns and sustain longer life-expectancy, more countries consider allowing investors to hold equities or equity mutual funds, in addition to the traditional fixed-income securities, in their retirement accounts. For example, United States investors can hold individual stocks in their 401(k) plans and IRA accounts; some European countries (Austria, Czech Republic, France, Germany, and United Kingdom) (DeGeorge et al. (2006)), Herbertsson and Orszag (1999) and Muller, Ryll and Wagener (1999)) started setting looser requirements for how individuals at small pension plans can invest directly in the stock market. Thailand and Malaysia in Asia also consider relaxing the regulations on whether investors can directly hold stocks in their retirement accounts (Asian Development Bank (1998)). Popular press, at the same time, has been advocating the tempting returns generated by investing in common stocks with retirement funds (Hardy (1982), and Kehrer (1991)), which may attract more individuals to the notion of equity investment for retirement.

If the trend to grant individuals greater autonomy in retirement investment were to spread around the globe, it is imperative for policymakers and participants to understand that greater investor autonomy and direct stock investments, which are believed to 
generate higher returns for retirements on average, could result in higher risks and grave consequences (Benartzi and Thaler (2002)).

One particular problem that emerges from the development of private retirement accounts in the United States is that participants invest heavily in the stocks of their employers. Such a bias was shown to cause severely under-diversified portfolios that will result in considerable welfare loss over a long investment horizon (Cohen (2005), Huberman and Jiang (2005)). Anecdotal evidence from the late 1990s suggests that employees of once successful companies such as Enron and WorldCom lost almost all of their investments in employer stocks, both through brokerage accounts and retirement plans, within a matter of months, alongside the downfall of the employers (Benartzi et al. (2004), Mitchell and Utkus (2005)).

A few gaps need be bridged before existing evidence in the United States can be used to advise further pension system reforms around the globe. First, because most U.S. studies focus on retirement plans sponsored by employers (i.e. 401(k) plans), which are predisposed to encourage employees holding employer stocks for retaining corporate control (Bethel et al. (1998), Gordon and Pound (1990), and Rauh (2005)), it remains unclear how individuals would invest in their 'private social security account', where there is little influence from the employers. Second, existing studies report considerably different results (please refer to Section 2 for a detailed discussion) regarding the magnitude of the problem, depending on the selected samples. This creates challenges for policymakers who look for a takeaway number when designing national-level reforms. 
Finally, investors in most developing financial markets do not enjoy the developed mutual fund industry as in the United States. According to Khorana et al. (2005), the mutual fund industry makes up less than 10 percent of domestic primary securities for 42 of the 56 the surveyed countries, most of which in the emerging markets. The lack of mutual funds conceivably makes investment choice for retirement more challenging and the cost of bias toward employer and under-diversification even higher. Therefore, additional studies on the bias toward employer stocks from markets with limited mutual fund presence will bring important lessons to many countries that face reforms in the pension system.

The current study attempts to fill the above gaps by investigating how the universe of employees at companies listed at the Taiwan Stock Exchange (TSE) treat employer stocks under little influence from institutional factors. Our data have the advantages of studying investors' attitudes toward employer stocks in an emerging market. Taiwanese market is unique in a sense that institutional influences, such as retirement plan design and employer matching, exerted little influence on individuals' decisions. Hence, we have the opportunity to investigate how investors treat employer stocks when they are under little influence from their employers.

The lack of alternative retirement plans during the sample period compels the sample individuals to plan their retirement by using at least part of their investment proceeds. We believe that our findings can therefore depict a picture similar to what 
individuals would do if they were to manage their private retirement or social security accounts, should the pension reform progress in many countries. Taiwanese investors resemble most individual investors in other developing markets, who have little access to the mutual fund industry. In addition, lessons from Taiwan show that certain behavioral patterns draw investors to their employer stocks, partly explaining the existing findings that investors in developed countries do not fully take advantage of the diversification offered by mutual funds. (Goetzmann and Kumar (2004), Goetzmann et al. (2004), and Zhu (2005)).

The findings, therefore, highlight the importance of providing well-diversified investment opportunities in social security accounts, if such accounts were 'privatized'. The development of the mutual fund industry and the financial market overall seems critical to the successful reform of the Social Security system. Our results hence offer important implications to global pension system reforms and urge policymakers around the world to reconsider relaxing 'safety net' requirement for retirement investment, given its possible costly consequences.

Another advantage of the data comes from the fact that we can observe portfolio choices for the entire universe of corporate employees from Taiwan. We can precisely estimate social cost not only at the market level, but also for respective investor segments. If the bias inflicts only some of the employees (i.e. corporate managers who are relatively well off), the problem of investing in employer stocks may not be as grave. However, if it is the rank and file employees, who need the investment most after retirement, that suffer 
more from the bias, policymakers on social security reform should be particularly alarmed.

Our findings are easy to summarize. Employees at TSE-listed companies hold a strikingly large proportion of their equity portfolios in employers' stocks. For all employees at the 442 companies that participate in Taiwan stock market, 71 percent held their own employer's stocks at the end of 1998. The employer stock makes up an average of 47 percent of the value of the personal portfolios (the median is 42 percent). Although this pattern is particularly strong for senior managers (55 percent), the results are very robust across different segments of employees.

Investor characteristics are important in explaining cross-sectional differences in employees' tendency to invest in employers. Employees who are older and have higher incomes invest more in employer stocks. Different from the common belief that managers invest heavily in employer stocks, rank and file employees are more susceptible to the bias on the percentage basis. When controlling for other investor characteristics, we find that senior managers indeed invest about 3 percentage points less of their portfolios in employer stocks than other employees do. Employees of companies with high book-to-market ratio, larger market capitalization, and employees at high-tech companies invest more in their employers. Past return and return volatilities also seem to matter to the bias. 
Individuals suffer considerably from investing in employers' stocks. There is little evidence that individuals gain abnormal returns by investing in local and familiar stocks. Instead, under-diversification resulting from the employer bias exposes individual portfolios to excessive idiosyncratic risks. If employees were to replace the 47 percent of their holdings in employer stocks with the market portfolio, they could obtain a higher return of 4.89 percent per annum, holding constant the current risk level. The foregone investment return in 1998 represents a striking 39.74 of investors' average annual salary in 1998. With the more conservative estimate for the median employee, the foregone return is still considerable at 11.54 percent of the 1998 income. It seems that investors lose considerably not only from active trading (Barber et al. (2005a)), but also from holding the wrong portfolios. Over the 27-year horizon before an average employee retires, portfolios free from employer bias can generate terminal value that is more than three times as large as individuals' observed choices. That is, the bias-free portfolio can sustain retirees three times as long as the observed portfolios, under the same spending pattern.

The rest of the study proceeds as follow: Section 2 reviews related literature; Section 3 describes background in Taiwan stock market and outlines the unique data on individual stock holdings and employment information; Section 4 presents empirical evidence that employees display strong bias toward employer stocks in Taiwan; Section 5 estimates the economic costs caused by the bias before we conclude in Section 6 . 


\section{Related Literature}

Scholars have dedicated considerable research to the reform of Social Security system and the defined contribution plans in the United States (Campbell and Feldstein (2001), Feldstein (1998), Feldstein and Siebert (2002)). One problem that attracts much recent attention in the United States defined contribution plan investment (i.e. 401(k) plans) is the bias toward employer stocks. Employees hold a large proportion of their retirement plans in employer stocks and incur significant costs by doing so (Benartzi (2001), Cohen (2005), Huberman and Sengmueller (2004). Meulbroek (2003) estimates that employees sacrifice about 42 percent of their retirement account holdings in employer stock due to the higher level of idiosyncratic risks. The under-diversification in equity portfolio is particularly hazardous because individuals usually do not hold diversified portfolios across different asset classes (i.e. stocks, bonds, and real estate etc.). ${ }^{1}$

Most current studies focus on individuals' bias toward employer stocks in retirement accounts (Agnew et al. (2001), Cogan and Mitchell (2003), Holden et al. (2000), Huberman et al. (2003), Ramaswamy (2002)). Because corporations are motivated to promote employees' share ownership as ways to defend hostile takeovers and retain corporate control (Bethel et al. (1998), Gordon and Pound (1990), and Rauh

\footnotetext{
${ }^{1}$ Wall Street Journal reports that half of IRA holders with Vanguard Group, a large mutual fund company and IRA custodian, put their entire accounts into stocks. ("Many Savers Failing to Diversify Net Eggs; Only Small Groups Found to be Making Trades, May Suffer 'Choice Overload',' Wall Street Journal (Eastern edition), November 28, 2005, Pg. C.9.)
} 
(2005)), it seems natural that individuals' bias toward employer stocks in retirement accounts may at least partly be induced by their companies. Agnew (2002), Benartzi (2001), Brown et al. (2005), Choi et al. (2005), and Huberman and Jiang (2005) all show that plan design, corporate matching policies, and plan default settings significantly influence employees' attitude toward employer stocks. What remains unclear is, should the social security reform progress further, how will individuals treat new employer stocks in their private social security account on which employers would play little roles. Research along this line will provide important policy implications for pension reform not only for the United States, but also for many other countries around the world that consider 'privatizing' social security.

If individuals frame retirement and other investment accounts separately, then the under-diversification in retirement accounts may go away if one considers the rest of individual portfolios. If instead, individuals exhibit similar bias towards employer stocks in other discretionary investment accounts (i.e. a private social security account) due to inherent behavioral biases (Barber, Odean and Zhu (2005), Kahneman (2003), and Kahneman and Tversky (1986), such as over-extrapolation (Benartzi (2001)), inertia (Choi et al. (2002)), and loyalty (Cohen (2005)), then the problem of investing in employer stocks looms even bigger. Many individuals will run into the hazard of holding severely concentrated retirement portfolios that could jeopardize their livelihood after retirement. Therefore, studies on retirement investment where institutional factors play little role are much needed. 
Depending on the selected samples, existing studies that examine the magnitude of the bias toward employer stocks generate mixed results. For example, the fraction of retirement plans invested in employer stocks ranges from 16 percent (Holden and VanDerhei (2004)) to over 40 percent (Brown et al. (2005), Huberman and Sengmueller (2004)) for a similar period of time (see Appendix A for a useful comparison of existing results and how the current study relates). Although it is completely understandable to have such considerable differences - because the bias towards employer stocks depends on firm characteristics, employee characteristics and corporate policies - (Choi et al. (2005), Cohen (2005)), future studies and policymakers will have difficulty in drawing reliable conclusions nationwide and determining appropriate policies to curb the adverse impact of such decisions. A thorough investigation of the bias by employees at all TSElisted companies from Taiwan can bridge this gap and yield a reliable estimate for the entire market.

\section{Background in Taiwan and Employee Stock Holding Data}

\section{A. Taiwan Stock Market}

The Taiwan stock market commands a total market capitalization of about \$NT 10 trillion (about $\$$ U.S. 313 billion) in the late 1990s, which ranked it as the $12^{\text {th }}$ largest equity market in the world. The listed stock market includes both stocks listed at the Taiwan Stock Exchange (TSE) and over-the-counter (OTC) stocks, with TSE dominating the total market capitalization, during the sample period. Among 509 TSE-listed 
companies during 1998, we focus on the 442 of which complete firm-level information is available from Taiwan Economic Journal (TEJ).

One apparent feature about Taiwan stock market is its high volatility. During the decade between 1993 and 2003, the average annual volatility is 32.3 percent, 72 percent greater than the volatility in the United States market during the same period. On the other hand, the average annual return is 10.5 percent, similar to that of U.S. market index. We plot the TAIEX (a value weighted index of all listed shares) movement during the decade in Figure 1. The high volatility underscores that sample selection has negligible impact on analyses on stock returns. Because we only have one year of data in 1998, we intentionally downplay employer bias' impact on individual portfolio returns but focus primarily on the consequent under-diversification.

We obtain firm-level information, such as firm size, market value, CAPM beta (calculated by performing the CAPM regression between 1996 and 1998 for each firm), past return and return volatility from the Taiwan Economic Journal (TEJ) and summarize it in Panel A of Table 1.

\section{B. Investor Position and Employment Information}

We obtain tax-filing data from Data Center at the Ministry of Finance of Taiwan that collects detailed household information for tax filing purposes, after the end of each calendar year. The data is similar to the information that the Internal Revenue Service 
(IRS) collects in the United States for household tax filing. For each household, we have the following three types of files: (1) the Income File that records different types of income data including salary, cash dividends and stock dividends that household members receive, and income tax levied on the household; (2) the Household Member File that records the characteristics (Age, Gender, and Relation, etc.) of each household member; and (3) the Stock Shareholders File that records the dollar amount invested in companies at the time of filing (the deadline is December 31 each year).

The data cover the entire investor universe. There are about 23 million populations in Taiwan as of 1998 and about 15 million filed taxes with taxable income. 6,676,100 individuals report income from salary, which identify them as employees of companies or organizations. 4,045,360 of such employees with income and salary above basic living standard are required to file for tax purposes and report their stock holdings. Among the 509 listed companies around in 1998, we focus on the 442 companies for which all required information is available. More than one third of total employees $(1,547,163)$ invest in the 442 sample companies in our file. These listed companies employ 210,103 people and the current study focuses on 167,116 of those who hold at least one listed company stock as revealed by stock shareholder data.

The foremost feature of the data is the information about an individual's employer. To our best knowledge, investors' employer information becomes available at the market level for the first time. We can obtain precise employer information about each individual from the Income File, which records each individual's employer and how much salary the 
individual earns from the company. Once identifying the investor's employer, we next match the employer information with individual portfolio holding data recorded in the Stock Shareholder File. Combining the employer information and stock holding data, we can calculate the fraction of individual portfolios that are invested in employer stocks, which reflect employees’ attitude toward employer stocks. Such data provide important additions to the transaction data featured in Barber et al. (2005a) and (2005b), in understanding of the behavior of Taiwanese investors. The closest data used in previous study are from Massa and Simonov (2005). However, they do not have data on the entire Swedish population, nor do they have precise employer information.

Several other distinct features of the data provide unique research opportunities. First, the data provide complete information for the entire Taiwanese population. Because investing in employer stocks can vary greatly depending on firm characteristics (such as firm size, plan design and firm past returns as in Benartzi (2001) and Choi et al. (2005), it is unreliable to draw conclusion on the social cost of investing in employer stocks based on evidence from any select group of companies. Complete data at the market level, therefore, enable us to accurately assess the social welfare cost resulting from the bias.

Our data are also unique in that employers play limited roles in investor decisions. Few options were granted for corporate executives or employees before 2002 and employee share ownership plans (ESOPs) (Kruse et al. (2005)) were rare during the sample period. Another distinct feature of option granting in Taiwan is that, unlike the practice in the United States, there is no lock-up requirement and employees can liquidate 
their awarded shares immediately (Han (2003)). Despite the fact that executives are occasionally awarded with employer stocks, supplemental data on executive compensation indicates that employee bonus and ESOP account for only an average 0.28 and 0.51 percent (the medians are both 0 ) of all outstanding shares for listed companies. Unlike in United States, there is no lock-up requirement for granted options in Taiwan during the sample period (Han (2003)), so executives can sell their awarded shares at any time, making awarded shares no different from shares obtained through open-market purchase. We also verify the limited role of option-granting with employee's income data. Even for the most senior executives, salary accounts for more than 92 percent of their total income. (\$NT 2,093,165/2,268,009 in Table 2.) The rest is made up from incomes from rents, investment proceeds, intellectual property, and professional services. Stock options account for less than one percent of the total income.

Fight for corporate control was rare in Taiwan during the entire 1990s and only one attempted hostile take-over took place during the decade (Qu (2003) and Guo (2005)). Therefore, corporations have little incentive to encourage employees holding their shares in order to fend off potential hostile takeover. This also distinguishes Taiwan from U.S. or nearby Hong Kong, where employers encourage employees holding their stocks to retain better control of the companies (Rauh (2005)).

Unlike United States investors who obtain shares through different channels brokerage accounts, retirement accounts, matching contributions from employers, option granting, ESOPs, etc. - Taiwanese investors obtain almost all of their shares from open- 
market transactions. ${ }^{2}$ Because there is no private pension plan practice in Taiwan, employers have less impact on households’ portfolio choice than their counterparts do in the U.S. This puts the current study in stark contrast with existing studies that focus on retirement plans, where employer matching policy and retirement plan design induce employees to hold company stocks.

Finally, the data enable us to distinguish company managers from rank and file employees. Examining whether managers hold more/less employer stocks than rank and file employees can indicate whether managers are over-confident about employer prospect or more sophisticated and hold more diversified portfolios. Studying whether managers can profit from holding employer stocks will provide additional evidence on whether employment-generated-familiarity can generate out-performance and whether managers can profit from their private information about the employers. More importantly, such information helps policymakers understand which employees are most susceptible to the bias toward employers and design specific actions targeted at helping rank and file employees.

\footnotetext{
${ }^{2}$ Similar to the practice in many other markets, companies tend to award shares to employees before initial public offerings (IPOs), which largely explain that employees at companies that went public in 1997 hold a much higher fraction (54 percent) of their portfolios in employer stocks, than those at companies that went public earlier (47 percent).
} 


\section{Taiwan Pension System in 1998}

The Social Security system in Taiwan deserves some further discussions. There was no universal Social Security plan in Taiwan during the sample period. National Health Insurance (NHI) and National Pension Program (NPP) reform took place in the late 1990s but was not put into effect until the turn of the century, and retirement benefits and insurance vary considerably among different social strata. Government employees, accounting for about 8 percent of population, are required to participate in retirement compensation plan that entitle them to a lump-sum old-age benefit of up to 34 months of salary by the Government Employee Insurance and an additional 53 months of salary or a monthly pension of 70 percent of pre-retirement basic salary offered by the Retirement Reserve Fund. Employees of companies made up about one third of the population in the 1990s and may receive up to a lump sum compensation of up to 50 months of salary. The remaining one half of the population is not covered by any public retirement insurance (Lin (2002)). Companies are under no legal obligations to provide retirement plans to employees and few employers offer any other forms of private pension plans. Consequently, we believe that most households count on proceeds from stock market investment as a major source of income after retirement and take such investment decisions seriously. In addition, stocks account for a much higher fraction (24 percent) of household assets, than deposits do (12 percent) in Taiwan (Directorate-General of Budget, Accounting and Statistics, Taiwan, http://www.dgbas.gov.tw/). 
Like many other developing markets (Khorana et al. (2005)), equity mutual funds were not well-developed in Taiwan during the sample period (Lin (2004), Shu et al. (2002)). The lack of a public retirement system and the immaturity of mutual fund industry imply that Taiwanese investors, especially those who have no other income sources after retirement, must plan to use part of their stock investments for retirement purpose (Lin (2002)). Consequently, the situation is similar to what investors would do should they have to invest their private social security account, under little influence from the employers or the retirement plans. Our findings suggest that, reasons other than plan design and employer incentives, which were rare in Taiwan during the sample period, are probably responsible for why investors tilt their retirement investment toward employer stocks in a global context.

\section{Bias toward Employer Stocks}

\section{A. Tendency to Invest in Employers' Stocks}

We first present evidence that Taiwan investors tend to invest an abnormally large proportion of their portfolios in employer stocks. Panel B of Table 2 reports that more than 70 percent of the 167,116 listed company employees (who receive salaries from listed companies in the tax filing file) own shares of their employers ${ }^{3}$. Senior employees

\footnotetext{
${ }^{3}$ If an investor were to randomly pick stocks, the probability of any investor owning his employers' stocks is $\mathrm{N} / 442$ (where $\mathrm{N}$ is the number of stocks held in portfolios and 442 is the number of listed companies in Taiwan in 1998). Given that average investors hold 3 stocks in their portfolios, a potential benchmark to compare against is 3/442, or less than 1 percent of listed-company employees are expected to hold employer shares.
} 
are much more likely to own company shares even when executive stock options were rare in 1998: 83 percent of senior management (whose salaries are above the top 5 percentile within each company) invest in employer stocks, as opposed to 65 percent for employees with salaries below the median salary at respective employers. Comparison between employees who invest and do not invest in employer stocks in Appendix B reveals that employees who invest in employer stocks tend to be male, older, and wealthier.

Another informative measure is the average fraction of portfolios that individuals invest in the employer stocks. We calculate the following fraction for each investor:

$$
\text { Percent in Employer }=\frac{\text { Investment }- \text { in }- \text { Employer }}{\text { Total }- \text { Investment }}
$$

where Investment-in-Employer is the dollar value invested in the employer's stocks and Total-Investment is the dollar value of all portfolio holdings.

Panel B of Table 2 reveals that TSE-listed company employees on average invest 47 percent of their portfolios in their employer's stocks (median=42 percent). 46.74 percent of all public company employees invest more than one half of their portfolios in respective employers' stocks and 27.22 percent of the employees invest their entire portfolios in employer stocks. Consistent with the above pattern, senior managers invest a higher fraction of their portfolio in employer stocks (55 percent) than rank and file 
employees (44 percent), despite that senior management hold much bigger portfolios (41 million compared to about 4 million Taiwan dollar).

It is striking that individuals hold about one half of their portfolios in a single stock of their employers. Such severe under-diversification is apparently detrimental from a return-to-risk perspective. To make things even worse, the single stock that investors bet heavily on is that of the employer's, from which they obtain a large fraction of their income (for detailed discussions, please refer to Benartzi et al. (2004), Meulbroek (2003)). It is therefore expected that such an investment strategy will post considerable costs to the entire society, ${ }^{4}$ which we will assess in Section 5.

\section{B. Investor Characteristics and Tendency to Invest in Employer Stocks}

Individuals exhibit different levels of behavioral biases (Dhar and Zhu (2006)) and some investors are more enthusiastic with employer stocks than others (Choi et al. (2002), Cohen (2005)). We then investigate which individuals favor employer stocks more in a regression setting. First, we perform probit regression in Table 3 to understand which employees are more likely to invest in employers. The dependent variable is a binary dummy variable that equals to 1 if an employee invests in her employer's stock

\footnotetext{
${ }^{4}$ We also examine the fraction for employees of all employers, regardless of whether the employers are listed companies. Individuals invest an average of 24 percent of their portfolio in their employers' stocks. The median value is zero. We believe this is a very conservative estimate because the whole sample includes mostly private companies and organizations, where employees cannot purchase employer shares through open market transactions.
} 
and 0 if she does not. Because our final sample only includes employees of listed companies who invest in the stock market, all employees fall in one of the two categories.

Investor characteristics include dummy variables for managers, logarithm of investor age, logarithm of investor income, and a gender dummy variable. The dummy variables for managers are constructed as follows. We sort all employees of each listed company by their salaries and consider investors with top 5/10/25 percentile salaries as managers. The top 5 percentile employees are most likely to include senior corporate managers and the top 10 and 25 percentile represent mid-level management (we use these terms interchangeably in the rest of the paper). The remaining 75 percent can be considered as the rank and file employees of companies. The senior 5/10/25 dummy variable takes the value of 1 if an investor's salary falls in the 5/10/25 percentile range and 0 otherwise. Investor age and income are observations in 1998 and the gender dummy variable takes value of 1 if an investor is male and 0 if she is female. The gender dummy is meant to control for difference in confidence and other behavioral biases between male and female employees (Barber and Odean (2001)). We also control other firm level information that will be discussed in Section 4.3.

Older employees and employees with higher taxable income are more likely to invest in employers. An investor who is 10 years older is 10 percent ( 1 times the coefficient of 0.10 ) more likely to invest in employers and an investor with \$NT 10,000 higher income is 168 percent (4 times the coefficient of 0.42 ) more likely to invest in 
employer stocks for a household with average reading of other characteristics. ${ }^{5}$ Managers are less likely to invest in the employers than rank and file employees when controlling for age and income. Senior managers are about 8 percent less likely to invest in the employers. The results may seem surprising because it is opposite to the summary statistics results in Table 2. This is entirely because we control for other investor characteristics in the regression setting. Because senior managers tend to be older and wealthier than other employees and older and wealthier investors are more likely to invest in employers, regression results depict an accurate picture of manager's propensity to invest in employers. Such results are in stark contrast with the findings from the U.S. (Malmendier and Tate (2005)) that CEOs on average own 2.3 percent (median=0.12 percent) of their employer stocks, much higher than the rank-and-file employees. We feel that the difference is largely due to that stock-based compensation is much more widely used in the U.S. male employees are slightly more likely to invest in employers.

We further perform two-sided tobit regression with the dependent variable as the percent of each portfolio invested in the employer stocks. The dependent variable is bounded by 0 and 1 to reflect that it is a measure of fraction. The tobit regression estimates investors' tendency to invest in employer stocks and how much they decide to invest in employers at the same time. As expected, most of the variables come out in the same direction as the probit regression.

\footnotetext{
${ }^{5}$ We calculate significance by using robust standard errors that account for clustering at employer level in all regression settings.
} 
Consistent with Choi et al. (2005) on employees from three U.S. companies, managers invest a smaller fraction of their portfolios in employer stocks, controlling other variables. This finding highlights that rank and file employees are indeed more susceptible to the mistake of investing in employer stocks. We conjecture that this is partly because senior managers have much bigger portfolios that can be diversified through other holdings or because they are more likely to understand the diversification principle or utilize professional services to manage their portfolios. Consistent with the probit results, age and income are positively related to the fraction invested in employers. Despite that male employees are more likely to invest in employer stocks, they invest about 4 percentage points less in employers than female employees do, when controlling for their choices.

\section{Firm Characteristics and Tendency to Invest in Employers}

Previous studies find that employees at companies with certain characteristics allocate more towards their employers in the retirement plans. For example, Benartzi (2001) shows that investors favor employer stocks more if company stocks have performed well in the past few years, and Cohen (2005) finds that employees of larger companies invest significantly more in their employers’ stocks.

We include firm level characteristics such as company market capitalization, market to book ratio, CAPM market beta, high-tech dummy, and past return and volatilities. Market capitalization is calculated by multiplying the total number of 
outstanding shares and the share price at December 31, 1998. Beta is calculated by running CAPM regression between January 1, 1996, and December 31, 1998, for each firm. High technology is a dummy variable that equals to 1 if a company is in computerrelated and bio-technology industry and 0 otherwise. Past one- and two-year return and volatility are the company returns between January 1, 1998/1997, and December 31, 1998 and the standard deviation of the monthly returns.

Consistent with U.S. findings, there is some evidence that investors hold more employer stock if the employer stocks perform relatively better. ${ }^{6}$ Interestingly, individuals’ response to employer stock return volatility depends heavily on the timehorizon. ${ }^{7}$ They increase employer stock holding for stocks with high 1-year volatility and decrease holding for stocks with high 2-year volatility. ${ }^{8}$ Similar to Cohen (2005), employees hold relatively more if employers have high market capitalization or the employer stock enjoys higher valuations, controlling for past returns. High-tech company employees hold more in employers' stocks, consistent with the notion that high-tech

\footnotetext{
${ }^{6}$ We also perform an alternative specification in which we calculate the fraction invested in employer stocks based on the number of shares, instead of dollar value, and obtain very similar results. Such results indicate that our findings are not likely to be driven by a mechanical relationship due to price appreciation of the employer stocks.

${ }^{7}$ It is worth noting that inference on past returns and volatility should both be taken with caution given that we only have one snapshot of household portfolio but not information on how households change their portfolio holdings.

${ }^{8}$ This may be attributed to the high-level of return volatility and the reversal of annual returns in the Taiwan stock market.
} 
company employees favor the employers ${ }^{9}$, without the common practice of option granting in U.S. high-tech companies in the 1990s. One potential reason that employees at high-tech companies hold more of their employer stocks is that such employers are more likely to use company stocks in awarding bonuses to employees. According to Chen et al. (2005), electronic companies, a large fraction of the high-tech companies, award an average of 84 percent of their bonuses with company stocks, much higher than the rest of the companies, where company stocks make up an average of 33 percent of the bonuses. However, consistent with our findings in Table 2, the authors also find that that salary commands more than 90 percent of household income for listed company employees and bonuses account only for less than 5 percent of household total income. Therefore, we believe that the reasons other than bonus, such as over-confidence with the employer, are responsible for the bias.

Our findings so far indicate that some inherent behavioral biases drive investors’ strong desire to invest in employers' stocks. This suggests that improvement in plan design alone cannot safeguard the security of future retirees. Legislators should reconsider how much autonomy individuals should have over their retirement and private social security accounts. In addition to the often-mentioned educational programs aimed at enhancing investor awareness of the bias and its cost, some constraints should be

\footnotetext{
${ }^{9}$ Given the positive correlation between the high-tech dummy and the beta of company stocks returns, we observe a somewhat surprising negative coefficient for the beta of company stock returns. When we perform a separate simple regression of the fraction invested in employer stocks and the beta of company stock returns, we find positive and significant coefficient, indicating that employees with 'riskier' companies invest more in employer stocks.
} 
imposed on the minimum fraction of portfolios invested in stock market index funds or other asset classes such as treasury bonds, and the maximum fraction of portfolios invested in employer stocks. Corporate policies should discourage employees to hold employer stocks to help improve employees' long-term welfare. Even if employees become aware of the costly bias and adjust their behavior with current contributions, their retirement accounts can remain sub-optimal because of inertia (please refer to Appendix B in Huberman and Sengmueller (2004) and Choi et al. (2002) for some more detailed discussion). Proactive programs such as Save-More-Tomorrow ${ }^{\mathrm{TM}}$ by Benartzi and Thaler (2004) should then be introduced to gradually achieve diversification in retirement accounts.

\section{Costs of Investment in Employers' Stocks}

Huberman et al. (2003) report that employer stocks as an investible option increases households' likelihood of participating in defined contribution pension plans. Similarly, we find that company stocks are effective in attracting employees to invest in the stock market. 79.5 percent of employees at listed companies participate in the stock market, much higher than the 23.2 percent for employees at private companies. However, it is puzzling as to why corporate employees forego the easily available diversification offered by the stock market and choose to invest in the riskier alternative of their own employers' stocks. 
One apparent reason why investors may favor employer stocks is that they may possess advantageous information about their employers. Existing studies are divided on whether familiarity generates value-relevant information. Ivkovich and Weisbenner (2005) and Massa and Simonov (2005) claim that investors obtain abnormal return by investing in nearby stocks but Huberman (2001) and Zhu (2004) argue that familiarity is not necessarily driven by information. Seasholes and Zhu (2005) show that Ivkovich and Weisbenner's results disappear when returns are measured with the correct calendar-time portfolio approach based on investor trades.

Because we only have a snapshot of investors' portfolios for one year, attempts to draw conclusion on whether investing in employers generates abnormal returns will be hindered by not only the limited power of the test but also the correlation in contemporaneous stock returns. In particular, we perform cross-sectional regression of the one-, two-, and five-year forward returns of each listed company on the fraction of each company's outstanding shares being held by all employees, senior managers, and middle managers, respectively. The coefficients for employee ownership in all specifications are negative yet insignificant, hinting that the more employees invest in their employers, the lower the employer stock returns are. Hence, it does not seem that employees can forecast employer stock returns.

In addition, we divide all sample employees into quartiles by the fraction of their portfolio invested in employer stocks. We next form four portfolios by pooling the portfolio positions by employees belonging to each quartile. Contrary to the claim that 
familiarity generates higher returns, the equal-weighted 1-year forward portfolio raw return is indeed 8.69 percent lower (significant at the 1 percent level) for portfolios by individuals who invest most in employer stocks than those who invest least. It is important to note that such a result is probably specific to the sample period. The difference remains negative yet becomes insignificant when we evaluate the 2-year and 5-year horizon, confirming that sample selection heavily influences the results over the shorter horizon. Given the respective limitation of above tests, neither of the above results is sufficient to conclude that individuals suffer lower returns by tilting portfolio toward their employers. Notwithstanding, there is hardly any evidence that individuals gain higher return by investing in employers, either.

Hence, we make no claim on whether individuals gain abnormal returns by investing in employers. Instead, we assume that investing in employer stocks does not influence individuals' portfolio return and focus exclusively on how employees suffer from the severe under-diversification resulting from the bias toward employers. We first summarize the one-year forward portfolio return and volatility and ask the question whether the portfolio choice can be improved by replacing the investment in employer stocks with randomly selected portfolios, such as a market index.

A simple comparison of the return and risk of the observed portfolio versus the bias-free portfolio by replacing company stocks with market index reveals that individuals could increase the returns and reduce the risk of their portfolios at the same time by investing less in employers. The average one-year forward monthly raw return is 
1.64 percent for observed portfolio and 2.34 percent for the market portfolio. ${ }^{10}$ The hypothetical bias-free portfolios outperform individuals' real portfolios by 20 basis points per month on the two-year horizon but lag the real portfolios by 9 basis points per month over the five-year horizon. Such findings are consistent with our earlier note that the return results are sensitive to sample selection and must be interpreted with caution.

In contrast, the hypothetical employer-bias-free portfolios are consistently less risky than the real portfolios. On the one-year horizon, the volatility of both the real and hypothetical portfolios is much higher (12.75 and 10.48 percent, respectively) than the market index volatility in 1998 (7.63 percent) and the ten-year average (9.33 percent) between 1993 and 2003. It is noteworthy that replacing employer stocks with market index reduces the portfolio risk by 17.8 percent. Over the two- and five-year horizon, portfolios free from employer bias also enjoy much lower level of risks than the observed portfolios (11.47 percent vs. 14.09 percent and 12.59 percent vs. 15.85 percent, representing a 18.6 and 20.6 percent reduction in portfolio risks). Above summary statistics confirm that under-diversification resulting from employer bias consistently hurts individuals’ welfare.

We next assess the economic significance of the losses caused by such underdiversification in Table 4. The essence of our estimation approach is to compare individual portfolios' return-to-risk ratio (i.e. Sharpe ratio) with the hypothetical portfolio

\footnotetext{
${ }^{10}$ The sizeable difference results from equal-weighting of very poor Sharpe ratios of individual portfolio, many of which are severely under-diversified.
} 
if individuals do not invest heavily in employers. By assuming no portfolio change between the tax-filing date and December 31, 1998, we first estimate each investor's monthly portfolio return and volatility in 1999, one year after forming the portfolio at the tax-filing deadline. Because return results are sensitive to the sample period, we construct the hypothetical portfolio for each individual by holding the observed portfolio return constant and replace the observed portfolio volatility with the volatility of the hypothetical portfolio free from employer bias. ${ }^{11}$ We next use the return and volatility information of the actual versus hypothetical portfolios in 1999 and calculate the Sharpe ratio for the observed versus the hypothetical portfolio to evaluate how return-to-risk ratio could be increased if individuals steer away from employer stocks.

The improvement is striking. The average Sharpe ratio increases from 0.068 to 0.099, an increase of almost 50 percent, if individuals were not to invest heavily in employer stocks. We next multiply the Sharpe ratio with the observed portfolio standard deviation and calculate how individual portfolio returns would change if individuals were to hold portfolios with current risk but do no tilt portfolios toward employers. The average employee can obtain a higher return 0.63 percentage point per month than the observed portfolio. The average annualized foregone return is 4.89 percent. $^{12}$

\footnotetext{
${ }^{11}$ We obtain very similar results when using 2 years and 5 years as hypothetical holding periods. Given that the turnover is high in the Taiwan stock market and particularly high for individual investors (See Barber et al. (2005a) and (2005b)), we feel the one-year holding period assumption is more appropriate.

${ }^{12}$ Because returns compound differently for different portfolios, the average annualized foregone return (4.89 percent) does not equal to average foregone return compounded at annual basis (7.83 percent).
} 
There are several ways of putting the foregone return into perspective. We first calculate the ratio of the foregone return in dollar value to individuals' salary income in 1998 in Table 5. For each individual, we multiply the foregone return with the 1998 yearend portfolio value and divide it by the 1998 salary income. We windsorize $1 \%$ of extreme observations on both tails because of outliers. Foregone return on average represents 39.74 percent of investor's last-year income. Such results have to be interpreted with caution because it is apparent that part of the result can be attributed to the fact that Taiwanese employees hold large portfolios relative to their incomes. At the same time, the magnitude of the portfolios exactly reflects that individuals probably plan to use at least part of their stock portfolios to support their retirement given the lack of other retirement plans in Taiwan. To avoid the influence from outliers, we also calculate the more conservative ratio of median portfolio value to median salary income in 1998. The ratio equals to 2.36 . By multiplying 2.36 with the average foregone return of 4.89 percent, we find that the foregone return still represents a considerable 11.54 percent of investor’s 1998 salary income.

It is evident from the above illustration that the bias toward employer stocks costs individuals nearly over the 1-year horizon. It should not be surprising that such a strategy causes even greater losses compounded over longer horizons. Based on summary statistics in Table 2, average employees are 38-year old and have 27 years until retirement. We assume the portfolio value to be $\$ \mathrm{NT} 339,906$, which is the median portfolio value for all Taiwanese employees. By assuming the expected future returns to be in line with the arithmetic average return during the decade around the sample year of 
1998 (between 1993 and 2003), employees' portfolios with the same level of risk, with or without employer bias will grow to \$NT 1,476,298 and \$NT 5,012,077, respectively. That is, investment without bias toward employers will generate more than three times as much wealth as individuals' real portfolios, holding portfolio risks constant. Using the median annual income of $\$ \mathrm{NT} 429,804$ for all investors, the terminal value of the investment strategy with and without employer bias can sustain the median investor for 6.87 and 23.32 years, at 50 percent of the 1998 income. Put differently, individuals' observed strategy generates wealth that can barely support retirees for 10 years. In contrast, the bias-free strategy can keep retirees through their life-expectancy (77.8 years in 1998).

It also helps to put the foregone returns in the context of U.S. market. If U.S. employees were to exhibit similar bias toward their employers (the fraction invested in employers in Taiwan 47 percent is indeed similar to some of the estimates in United States for retirement plan accounts (Brown et al. (2005), Huberman and Sengmueller (2004)), we can estimate in Panel B of Table 5 how much average U.S. employees would give up. According to Holden and VanDerhei (2004), average account balance for active 401(k) plan participants is $\$ 57,668$. We assume that an individual invests through market index and obtains the historical average return of 12.3 per annum during the past 50 years. With an additional assumption of investment horizon for 20 years until retirement, the investor will receive $\$ 587,903$ terminal value at retirement. Instead, if she keeps her portfolio risk constant and tilts their portfolios toward employers as the average Taiwanese investor does and gives up 4.89 percent per year, the terminal value will be 
$\$ 241,346$, less than one half of the value if individuals were not to bias toward the employers. The above examples both demonstrate that the bias toward employer stocks can incur such high cost to employees that retirees' livelihood after retirement will be jeopardized.

Needless to say, the above outcomes have drastically different implications on social stability and government responsibilities. Younger generations would have to bear greater burden if the older ones did not obtain enough from the retirement investments. It is likely that individuals may have other types of investments such as savings and real estate. Notwithstanding, if one were to assume that private retirement accounts make up the majority of retirees' income, as will happen under the regime of private social security account, our findings in Taiwan expose the hazard of giving individuals too much autonomy over their retirement accounts. It seems that employment with a listed company greatly increases someone's chance of investing in employer stocks and holding under-diversified portfolios, and may cause catastrophic consequences.

\section{Conclusions}

We utilize comprehensive data from Taiwan to show that employees of TSElisted companies invest about one half of their portfolios in their employers' stocks. The economic cost of doing so is considerable. Investors on average give up 4.89 percent of raw returns per annum by holding their employers' shares, equal to 39.74 percent of their 1998 salary income. Such allegiance to employer stocks cannot be attributed to executive 
option compensation, ESOPs, sponsoring policies by employers to own company stocks, plan designs, or private information. Instead, behavioral biases, such as availability and salience heuristics, inertia, over-confidence, and over-extrapolation are possible reasons behind the phenomenon.

Different from previous findings drawn from retirement accounts in the United States, our findings suggest that investing in employer stocks is generic to individual investor decision-making, but not limited to their decisions in the context of investing for retirement. The findings emphasize that although improving plan design and company sponsoring policy could alleviate the severe under-diversification in retirement plans to some extent, it is highly plausible that individuals will choose to invest sub-optimally in employer stocks even when companies do not actively encourage employees to hold their shares.

Our study underscores the potential pitfall that investors may face if social security is 'privatized' and motivates policy changes that will safe-guard retirees' security through social security reform. The findings are important for countries considering reforming their social security. Any attempt to 'privatize' social security must be based on very careful consideration of individual behavioral biases and potential mistakes. Unnecessarily risky investments can result in a loss of security after retirement and impose consequential problems to financial markets and social stability. The lessons from Taiwan clearly stress the need to provide well-diversified alternatives for 
individuals to invest for their retirement, given their behavioral biases and failure to diversify in their autonomous accounts.

Future studies are needed in the following areas. First, further studies are required to understand why individuals have such strong attachment to employer stocks as reported in this study. Only after understanding the behavioral mechanism behind the loyalty phenomenon can scholars and policymakers determine the best way to help investors avoid the bias. Second, institutional differences in retirement arrangements around the world can provide valuable opportunities to compare and contrast the costs and benefits of competing systems and engender policy proposals that better ensure employees’ welfare. Finally, future research should come up with specific mechanisms that can limit employee's enthusiasm for their employers' stocks. It is worth emphasizing that employees hardly have any information advantage on their employers compared to other investors and investing in other vehicles such as mutual funds should be advocated. 


\section{References}

Agnew, Julie. "Inefficient Choices in 401(k) Plans: Evidence from Individual Level Data.” Journal of Financial and Quantitative Analysis, forthcoming, (2002).

Agnew, Julie; Pietro Balduzzi; and Annika Sunden. "Portfolio Choice, Trading, and Returns in Large 401(k) Plan.” American Economic Review, 93 (2001), 193-215.

Asian Development Bank. "Policy Options for Pension Reform in Asia: Challenges in Design and Implementation.” Technical Assistance Reports, (1998).

Barber, Brad; Yi-Tsung Lee; Yu-Jane Liu; and Terrance Odean. "How Much is Lost to Trade?: Evidence from Taiwan.” Working Paper, University of California, Davis (2005a).

Barber, Brad; Yi-Tsung Lee; Yu-Jane Liu; and Terrance Odean. "Do Individual Day Traders Make Money? Evidence from Taiwan.” Working Paper, University of California, Davis (2005b).

Barber, Brad, and Terrance Odean. "Boys will be Boys: Gender, Overconfidence and Common Stock Investment.” Quarterly Journal of Economics, (2001), 261-292.

Barber, Brad; Terrance Odean; and Ning Zhu. “Do Noise Traders Move the Market?” Working Paper, University of California, Davis (2005).

Benartzi, Shlomo. "Excessive Extrapolation and Allocations of 401(k) Accounts to Company Stocks.” Journal of Finance, 56 (2001), 1747-64.

Benartzi, Shlomo, and Richard H. Thaler. "How Much Is Investor Autonomy Worth?” Journal of Finance, 57 (2002), 1593-1616.

Benartzi, Shlomo, and Richard H. Thaler. "Save More Tomorrow: Using Behavioral Economics to Increase Employee Savings.” Journal of Political Economy, 112, Part 2 (2005), S164-S187.

Benartzi, Shlomo; Richard H. Thaler; Stephen P. Utkus; and Cass R. Sunstein. "Company Stock, Market Rationality, and Legal Reform.” Working Paper, University of Chicago Law School (2005).

Bethel, Jennifer E.; Julia Porter Liebeskind; and Tim Opler. "Block Share Purchases and Corporate Performance.” Journal of Finance, 53 (1998), 605-634.

Brown, Jeffrey; Nellie Liang; and Scott Weisbenner. "401(k) Matching Contributions in Company Stock - Costs and Benefits for Firms and Workers.” Journal of Public Economics (2005), forthcoming.

Campbell, John, and Martin Feldstein. Risk Aspects of Investment-based Social Security Reform. University of Chicago Press (2001).

Chen, Chun-Ho; Chan-Jane Lin; and Tsai Yann-Ching. "The Association between Employee Bonus and Subsequent Firm Performance: Evidence from Electronic Industry in Taiwan.” Working Paper, National Taiwan University (2005). 
Choi, James; David Laibson; Brigitte Madrian; and Andrew Metrick. "Defined Contribution Pensions: Plan Rules, Participant Decisions and the Path of Least Resistance.” Tax Policy and the Economy, 16, MIT Press (2002).

Choi, James; David Laibson; Brigitte Madrian; and Andrew Metrick. "Employees' Investment Decisions About Company Stock.” in Pension Design and Decision-Making Under Uncertainty, Olivia S. Mitchell and Stephen P. Utkus, eds. Oxford University Press (2005).

Cogan, John, and Olivia Mitchell. "Perspectives from the President's Commission on Social Security Reform.” Journal of Economic Perspective, 17 (2003), 149-172.

Cohen, Lauren. “Loyalty Based Portfolio Choice.” Working Paper, University of Chicago (2005).

DeGeorge, Francois, Dirk Jenter, Alberto Moel, and Peter Tufano, 2006, Selling Company Shares to Reluctant Employees: France Telecom's Experience, Journal of Financial Economics, 71, (2002), 169-202.

Dhar, Ravi, and Ning Zhu. "Up Close and Personal: An Individual Level Analysis of the Disposition Effect.” Management Science, 52 (2006), 726-740.

Feldstein, Martin. Privatizing Social Security. University of Chicago Press (1998).

Feldstein, Martin, and Horst Siebert. Social Security Pension Reform in Europe. University of Chicago Press (2002).

Goetzmann, William, and Alok Kumar. "Why Individual Investors Hold Under-Diversified Portfolios.” Working Paper, Yale University (2004).

Goetzmann, William; Massimo Massa; and Andrei Simonov. "Portfolio Diversification and City Agglomeration.” Working Paper, Yale University (2004).

Gordon, Lilli A., and John Pound. "ESOPs and Corporate Control.” Journal of Financial Economics, 27 (1990), 525-555.

Guo, Yu-Fane. “A Summary of the Regulations on Tender Offers.” Securities and Futures Monthly, 23 (2005), 12-23.

Han, Tzu-Shian. “The Economic Effects of Profit Sharing and Taiwan-style Employee Stock Owner ship Plans: Evidence from Taiwan's High-tech Firms.” Taiwan Management Journal, 3 (2003), 1-22.

Hardy, Colburn D. ABCs of Investing Your Retirement Funds. $2^{\text {nd }}$ Edition, Oradell, NJ: Medical Economic Books (1982).

Herbertsson, Thor Tryggvi, and Michael J. Orszag. "Issues in European Pension Reforms, Supplementary Pensions.” Working Paper, University of London (1999).

Holden, Sarah, and Jack VanDerhei. "401(k) Plan Asset Allocation, Account Balances and Loan Activity in .” Investment Company Institute Perspective, 10 (2004). 
Holden, Sarah; Jack VanDerhei; and Carol Quick. “401(k) Plan Asset Allocation, Account Balances, and Loan Activity in 1998.” Investment Company Institute Perspective, 6 (2000).

Huberman, Gur. "Familiarity Breeds Investment.” Review of Financial Studies, 14 (2001), 659680.

Huberman, Gur; Sheena Iyengar; and Wei Jiang. "Defined Contribution Pension Plans: Determinants of Participation and Contribution Rates.” Working Paper, Columbia University (2005).

Huberman, Gur, and Wei Jiang. "Offering vs. Choice in 401(k) Plans, Equity Exposure and Number of Funds.” Journal of Finance, (2005), forthcoming.

Huberman, Gur, and Paul Sengmueller. "Performance and Employer Stock in 401(k) Plans." Review of Finance, 8 (2004), 403-443.

Ivkovich, Zoran, and Scott Weisbenner. "Local Does as Local Is: Information Content of the Geography of Individual Investors’ Common Stock Investments.” Journal of Finance, 60 (2005), 267-306.

Kahneman, Daniel. "Maps of Bounded Rationality: Psychology for Behavioral Economics.” American Economic Review, 93 (2003), 1449-1475.

Kahneman, Daniel, and Amos Tversky. "Rational Choice and the Framing of Decisions.” Journal of Business, 59 (1986), 251-278.

Kehrer, Daniel. The Pension Plan Investor. Probus Publishing Company, Chicago, IL (1991).

Khorana, Ajay; Henri Servaes; and Peter Tufano. "Explaining the Size of the Mutual Fund Industry around the World.” Journal of Financial Economics, 78 (2005), 145-185.

Kruse, Douglas; Richard Freeman; Joseph Blasi; Robert Buchele; and Adria Scharf. "Motivating Employer-Owners in ESOP Firms: Human Resource Policies and Company Performance." Working Paper 10177, NBER (2005).

Leone, Richard C., and Greg Anrig (Eds). Social Security Reform: Beyond the Basics. The Century Foundation (1999).

Lin, Chen-Wei. The Developing Economies, XL-3 (2002), 327-358.

Lin, Qiu-Jin. "The Past, Present, and Future of Taiwan Mutual Fund Industry." Wealth Management, 1 ( http://fw.fundwatch.com.tw/newfw/wm/catalog.jsp?allqtype=02) (2004).

Malmendier, Ulrike, and Geoffrey Tate. "CEO Overconfidence and Corporate Investment." Journal of Finance, (2005), forthcoming.

Massa, Massimo, and Andrei Simonov. "Hedging, Familiarity, and Portfolio Choice." Review of Financial Studies, (2005), forthcoming.

Meulbroek, Lisa. “Company Stock in Pension Plans: How Costly Is It?” Working Paper 02-058, Harvard Business School (2003). 
Mitchell, Olivia S., and Stephen P. Utkus. "Company Stock and Retirement Plan Diversification.” Working Paper, Wharton School, University of Pennsylvania (2003).

Muller, Katharina; Andreas Ryll; and Hans-Jurgen Wagener (Eds). Transformation of Social Security: Pensions in Central-Eastern Europe. Germany: Physica-Verlag (1999).

Qu, Qiu-Fang. “On the Legality of Share Repurchase in the Even of Hostile Takeover.” TSEC Monthly Review, No. 498 (2003), 33-59.

Ramaswamy, Krishna. "Company Stock and DC Plan Diversification.” Working Paper, University of Pennsylvania (2005).

Rauh, Joshua. "Own Company Stock in Defined Contribution Pension Plans: A Takeover Defense?” Journal of Financial Economics, (2005), forthcoming.

Seasholes, Mark, and Ning Zhu. "Is There Information in the Local Portfolio Choices of Individuals.” Working Paper, University of California, Davis (2005).

Shu, P.-G.; Y.-H. Yeh; and T. Yamada. "The Behavior of Taiwan Mutual Fund InvestorsPerformance and Fund Flows.” Pacific-Basin Finance Journal, 10 (2002), 583-600.

Zhu, Ning. "The Local Bias of Individual Investors.” Working Paper, University of California, Davis (2004).

Zhu, Ning. "Cost of Time and Household Choice between Direct and Delegated Investments." Working Paper, University of California, Davis (2005). 
Figure 1. Cumulative TAIEX Returns between January 1993 and December 2003

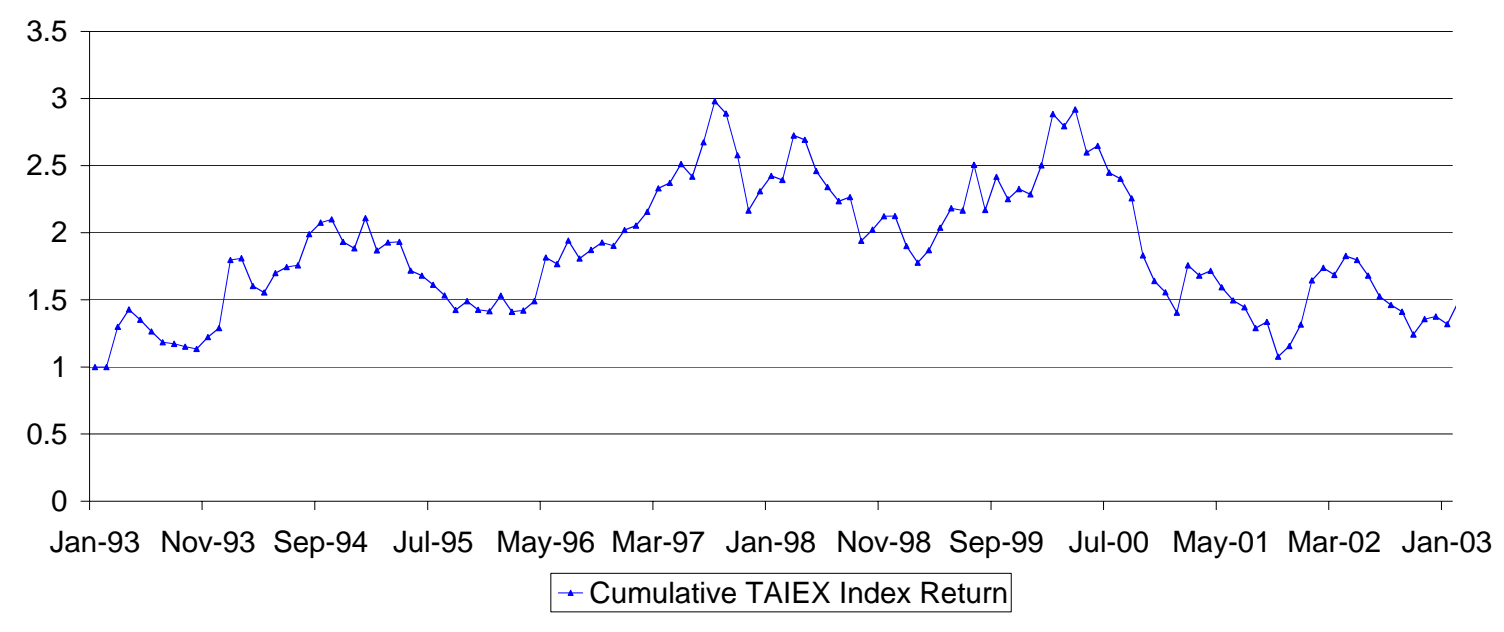


Table 1. Summary Statistics

\section{Panel A. Firm Characteristics}

M/B

Beta

Size (in thousands of \$NT)

Annualized one-year forward return

Annualized two-year forward return

Annualized five-year forward return

Annualized one-year past-return

Annualized two-year past return

Annualized five-year past return

\section{Mean}

2.97

1.05

107,805

$32.09 \%$

$-15.82 \%$

$1.57 \%$

$11.32 \%$

$53.39 \%$

$24.82 \%$
Standard deviation

0.17

0.02

6,202

$3.70 \%$

$1.23 \%$

$0.68 \%$

$1.48 \%$

$406.00 \%$

$1.67 \%$

Panel B. Investor Sample Construction 


\begin{tabular}{cc}
\hline Number of & Percent of employees \\
Observations & \begin{tabular}{c} 
investing in employers \\
\hline
\end{tabular} \\
\hline
\end{tabular}

Total Population

Individuals with identified income

Individuals with Income and salaries

Individuals with Income and salary above basic

standard

Investors in listed markets

Employees of listed companies

Employees of listed companies invest in the listed market

employees of listed companies who own company stocks
23 million

$14,541,662$

$6,676,100$

$4,045,360$

$1,547,163$

210,103

167,116

$100.00 \%$

118,081

$70.66 \%$ 


\section{Table 2. Bias toward Employer Stocks}

\section{Panel A. Investor Characteristics}

\begin{tabular}{|c|c|c|c|c|c|c|}
\hline & All Investors & $\begin{array}{l}\text { All Employess of } \\
\text { Listed Companies }\end{array}$ & Senior 05 & Senior 10 & Senior 25 & Senior \\
\hline Number of Observation & $1,547,163$ & 210,103 & 14,711 & 28,552 & 67,447 & 125,7 \\
\hline Age & $\begin{array}{c}40.82 \\
(11.61)\end{array}$ & $\begin{array}{c}37.73 \\
(10.00)\end{array}$ & $\begin{array}{l}46.04 \\
(9.11)\end{array}$ & $\begin{array}{l}44.16 \\
(8.97)\end{array}$ & $\begin{array}{l}41.55 \\
(9.03)\end{array}$ & $\begin{array}{l}39.5 \\
(9.34\end{array}$ \\
\hline Income & $\begin{array}{c}429,804 \\
(542,246)\end{array}$ & $\begin{array}{c}812,181 \\
(820,424)\end{array}$ & $\begin{array}{c}2,268,009 \\
(2,278,074)\end{array}$ & $\begin{array}{c}1,793,831 \\
(1,753,092)\end{array}$ & $\begin{array}{c}1,310,174 \\
(1,248,700)\end{array}$ & $\begin{array}{l}1,025,2 \\
(981,2 €\end{array}$ \\
\hline Salaries & $\begin{array}{c}402,624 \\
(492,767)\end{array}$ & $\begin{array}{c}779,977 \\
(665,378)\end{array}$ & $\begin{array}{c}2,093,165 \\
(12,642,405)\end{array}$ & $\begin{array}{c}1,688,296 \\
(1,277,460)\end{array}$ & $\begin{array}{l}1,310,174 \\
(949,918)\end{array}$ & $\begin{array}{l}1,025,2 \\
(770,2\end{array}$ \\
\hline Number of Shares Invested & $\begin{array}{c}179,110 \\
(72,822,122)\end{array}$ & $\begin{array}{c}147,710 \\
(3,751,474)\end{array}$ & $\begin{array}{c}1,444,369 \\
(12,642,405)\end{array}$ & $\begin{array}{c}807,116 \\
(9,150,151)\end{array}$ & $\begin{array}{c}376,801 \\
(5,991,344)\end{array}$ & $\begin{array}{r}219,52 \\
(4,404,4\end{array}$ \\
\hline Dollar Value of Investment & $\begin{array}{c}4,313,174 \\
(156,833,289 \\
) \\
\end{array}$ & $\begin{array}{c}4,272,364 \\
(125,115,369) \\
\end{array}$ & $\begin{array}{r}41,709,761 \\
(436,108,418) \\
\end{array}$ & $\begin{array}{c}23,240,578 \\
(315,225,725) \\
\end{array}$ & $\begin{array}{r}10,824,114 \\
(206,129,503) \\
\end{array}$ & $\begin{array}{r}6,311,6 \\
(151,476 \\
\end{array}$ \\
\hline Panel B. Portfolio Summ & & & & & & \\
\hline Number of Observation & $1,547,163$ & 210,103 & 14,711 & 28,552 & 67,447 & 125,7 \\
\hline
\end{tabular}


Number of Observations

where Employees Invest in

167,116

118,081

$70.66 \%$

Employees/Investor that

Invest in Employer Stocks

Fraction of Portfolio Invested in Employer Stocks 
Table 3. Factors that Influence Investors’ Tendency to Invest in Employer Stocks

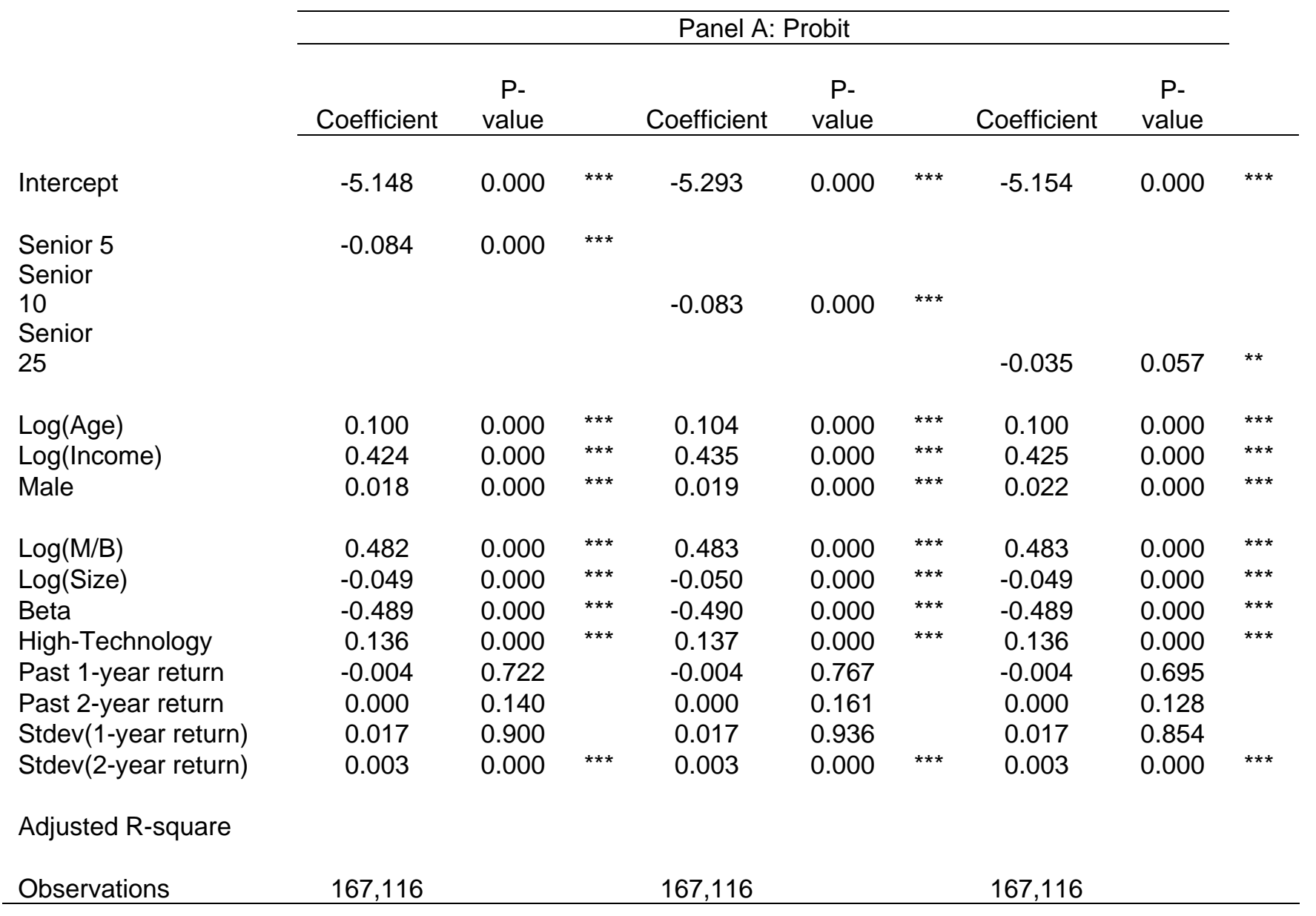


Intercept

Senior 5

Senior 10

Senior 25

$\log$ (Age)

Log(Income)

Male

$\log (\mathrm{M} / \mathrm{B})$

Log(Size)

Beta

High-Technology

Past 1-year return

Past 2-year return

Stdev(1-year

return)

Stdev(2-year

return)

Adjusted R-

square

Observations

\begin{tabular}{|c|c|c|c|c|c|c|c|c|}
\hline \multicolumn{9}{|c|}{ Panel B: Tobit } \\
\hline Coefficient & P-value & & Coefficient & P-value & & & Coefficient & P-value \\
\hline-164.709 & 0.000 & $* \star *$ & -171.794 & 0.000 & $\star \star \star *$ & & -166.148 & 0.000 \\
\hline \multirow[t]{3}{*}{-3.257} & 0.002 & $* * *$ & & & & & & \\
\hline & & & -3.599 & 0.000 & $\star \star *$ & & & \\
\hline & & & & & & & -1.843 & 0.005 \\
\hline 18.816 & 0.000 & $\star * *$ & 18.804 & 0.000 & $\star * *$ & & 18.660 & 0.000 \\
\hline 11.327 & 0.000 & $* * *$ & 11.875 & 0.000 & $\star \star \star *$ & & 11.453 & 0.000 \\
\hline-3.925 & 0.000 & $* * *$ & -3.900 & 0.000 & $\star \star *$ & & -3.730 & 0.000 \\
\hline-21.641 & 0.000 & $\star * *$ & -21.545 & 0.000 & $\star * *$ & & -21.557 & 0.000 \\
\hline 1.084 & 0.000 & & $* * *$ & & 1.004 & 0.000 & $\star \star \star$ & \\
\hline-12.937 & 0.000 & & $\star \star \star$ & & -12.920 & 0.000 & $\star * *$ & \\
\hline 44.425 & 0.000 & & $\star \star \star$ & & 44.565 & 0.000 & $\star \star *$ & \\
\hline-0.004 & 0.793 & & -0.005 & 0.749 & & & -0.004 & 0.793 \\
\hline 0.066 & 0.000 & $\star \star \star *$ & 0.066 & 0.000 & $\star \star \star *$ & & 0.066 & 0.000 \\
\hline 0.193 & 0.004 & $\star * \star$ & 0.196 & 0.003 & $\star * *$ & & 0.192 & 0.004 \\
\hline-0.622 & 0.000 & $\star \star \star \star ~$ & -0.625 & 0.000 & $\star \star \star$ & & -0.625 & 0.000 \\
\hline 167,116 & & & 167,116 & & & & 167,116 & \\
\hline
\end{tabular}


Table 4. Costs of Investing in Employer Stocks

Investors' portfolio $\quad$ Market Portfolio

$47.4 \%$

1.637

2.338

12.752

7.631

0.288

Risk Free Rate

0.068

Sharpe Ratio

0.099

Sharpe Ratio without under-diversification

$-0.031$

Cost of under-diversification Sharpe Ratio ( C )

C*Standard deviation of Returns

$-0.631$

Cost of under-diversification in Annualized

Foregone Returns (\%)

$-4.89 \%$ 
Table 5. Foregone Returns in Retirement Investments from Bias toward Employer Stocks

Investing in Market Index

Bias toward Employer

Panel A. Taiwanese Invesetors

Starting balance

investment horizon

Annual market return (1993-2003)

Cumulative return over the investment horizon

Terminal value if investing in market index

\begin{tabular}{cc}
\multicolumn{2}{c}{ Panel A. Taiwanese Invesetors } \\
\hline \$NT 339,906 & \$NT 339,906 \\
27 years & 27 years \\
$10.48 \%$ & $5.59 \%$ \\
$1474.55 \%$ & $434.33 \%$ \\
\$NT 5,012,077.77 & \$NT 1,476,298.43 \\
\hline
\end{tabular}

Panel B. U.S. Investors

Starting balance

$\$ 57,668$

$\$ 57,668$

investment horizon

20 years

20 years

Annual market return (1953-2003)

$12.31 \%$

$7.42 \%$

Cumulative return over the investment horizon

$1019.46 \%$

$418.51 \%$

Terminal value if investing in market index

$\$ 587,902.19$

$\$ 241,346.35$ 


\section{Appendix A. Comparison and contrast between current study and existing studies on investment in employer stocks in the United States}

\begin{tabular}{cccccc}
$\begin{array}{c}\text { Number of } \\
\text { Plans }\end{array}$ & $\begin{array}{c}\text { Number } \\
\text { of } \\
\text { companies }\end{array}$ & $\begin{array}{c}\text { Number of } \\
\text { participants }\end{array}$ & Value of Assets & $\begin{array}{c}\text { Time } \\
\text { Period }\end{array}$ & $\begin{array}{c}\text { Average percent } \\
\text { invested } \\
\text { employer stock }\end{array}$ \\
\hline
\end{tabular}

Benartzi (2001)

Brown, Liang and Weisbenner (2005)

Choi et al. (2005)

Cohen (2005)

Holden and VanDerhei (2003)

Huberman and Sengmueller (2004)

Mitchell and Utkus (2005)

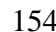

N/A

N/A

N/A

46,310

335
N/A

1,377

13.17 million

\$1,377 billion

\$8.4 billion

\$142 billion

263

N/A

$15,509,185$

N/A
1993

$1991-2000$

1993-2000

$1997-2000$

2002

1994-1998
$23 / 24 *$

17 to 45.5 **

17.7

17.3 to $20.6 * * *$

$16 * * * * * *$

35-40(1993-1998)

$300,592 * * * *$

N/A

11 million

1,541 billion*****

1993-1998

$15.5-17.4$

U.S. Department of Labor

Benefit Research Institute (EBRI)

and Investment Company Institute (ICI) 


(n)

N/A

$442 \quad 167,116$
\$NT 713.98 billion
(US\$ 22.16

1998

billion)
Employee Benefit Research Institute (EBRI)
and Investment Company Institute (ICI)

Current Study

* depending on equal weighted vs. weighted by plan contributions; ** 17 percent for unrestricted match and 45.5 percent for company stock match; *** 17.3 percent for conglomerate firms and 20.6 for stand-alone firms; **** 401(k) only, as of 1998; ***** 401(k) only, as of 1998 ; ****** As of 1998. 


\section{Appendix B. Characteristics for investors who invest and do not invest in employer stocks}

\begin{tabular}{|c|c|c|c|c|c|c|}
\hline \multirow[b]{2}{*}{ Age $<18$} & \multicolumn{2}{|c|}{$\begin{array}{l}\text { Employees who invest in } \\
\text { employer stocks }\end{array}$} & \multicolumn{2}{|c|}{$\begin{array}{l}\text { Employees who do NOT } \\
\text { invest in employer stocks }\end{array}$} & \multicolumn{2}{|c|}{$\begin{array}{l}\text { Employees who invest } \\
\text { in listed companies }\end{array}$} \\
\hline & 7 & $0.01 \%$ & 1 & $0.00 \%$ & 8 & $0.00 \%$ \\
\hline Age18-25 & 5,766 & $4.88 \%$ & 2,283 & $4.66 \%$ & 8,049 & $4.82 \%$ \\
\hline Age 26-64 & 110,800 & $93.83 \%$ & 46,322 & $94.47 \%$ & 157,122 & $94.02 \%$ \\
\hline Age $>=65$ & 1,508 & $1.28 \%$ & 429 & $0.87 \%$ & 1,937 & $1.16 \%$ \\
\hline Gender (Male) & 69,343 & $58.72 \%$ & 26,242 & $53.52 \%$ & 95,585 & $57.20 \%$ \\
\hline Tax $<13 \%$ & 108,963 & $92.28 \%$ & 47,439 & $96.75 \%$ & 156,402 & $93.59 \%$ \\
\hline $\operatorname{Tax}(13-21 \%)$ & 7,378 & $6.25 \%$ & 1,407 & $2.87 \%$ & 8,785 & $5.26 \%$ \\
\hline $\operatorname{Tax}(21-30 \%)$ & 1,103 & $0.93 \%$ & 135 & $0.28 \%$ & 1,238 & $0.74 \%$ \\
\hline $\operatorname{Tax}>=31 \%$ & 637 & $0.54 \%$ & 54 & $0.11 \%$ & 691 & $0.41 \%$ \\
\hline Total & 118,081 & & 49,035 & & 167,116 & \\
\hline
\end{tabular}




\section{RECENT WORKING PAPERS FROM THE}

\section{CENTER FOR RETIREMENT RESEARCH AT BOSTON COLLEGE}

Health Insurance and the Labor Supply Decisions of Older Workers: Evidence from the U.S. Department of Veterans Affairs

Melissa A. Boyle and Joanna N. Lahey, November 2007

Why Are Companies Freezing Their Pensions?

Alicia H. Munnell and Mauricio Soto, November 2007

Capital Income Flows and the Relative Well-Being of America's Aged Population Barry P. Bosworth, Gary Burtless, and Sarah E. Anders, November 2007

The Role of Governance in Retirement Investments: Evidence from Variable Annuities

Richard Evans and Rudiger Fahlenbrach, October 2007

A New Approach to Raising Social Security's Earliest Eligibility Age

Kelly Haverstick, Margarita Sapozhnikov, Robert Triest, and Natalia Zhivan, October 2007

What Makes Retirees Happier: A Gradual or 'Cold Turkey' Retirement?

Esteban Calvo, Kelly Haverstick, and Steven A. Sass, October 2007

Why Do Married Men Claim Social Security Benefits So Early? Ignorance, Caddishness, or Something Else?

Steven A. Sass, Wei Sun, and Anthony Webb, October 2007

Measurement Error in Earnings Data in the Health and Retirement Study Jesse Bricker and Gary V. Engelhardt, October 2007

Evaluating the Advanced Life Deferred Annuity - An Annuity People Might Actually Buy

Guan Gong and Anthony Webb, September 2007

Population Aging, Labor Demand, and the Structure of Wages

Margarita Sapozhnikov and Robert K. Triest, September 2007

Work at Older Ages: Is Raising the Early Retirement Age an Option for Social Security Reform?

John A. Turner, August 2007 